\title{
Environmental assessment of pediatric Lead exposure in Tehran; a prospective cross-sectional study
}

\author{
Hedieh Ahangar ${ }^{1}$, Afsoon Karimdoost ${ }^{1}$, Amir Salimi ${ }^{2}$, Maryam Akhgari ${ }^{3}$, Scott Phillips ${ }^{4}$, Nasim Zamani ${ }^{5,6}$, \\ Nasibeh Hassanpour ${ }^{1}$, Ali-Asghar Kolahi ${ }^{5}$, Gary R. Krieger ${ }^{7}$ and Hossein Hassanian-Moghaddam ${ }^{5,6^{*}}$ (D)
}

\begin{abstract}
Background: Ingestion and inhalation are common routes of exposure for lead in humans. Developing countries still have unacceptably high rates of lead toxicity, especially in children. Studies on probable risk factors of lead poisoning in Iranian children are insufficient. In this study, we aimed to evaluate possible environmental factors in children with high blood lead concentrations living in Tehran and neighboring cities.

Methods: In a prospective cross-sectional study between March 2018 and March 2019 we followed all children referred from two pediatric gastrointestinal clinics with blood lead level (BLL) $>5 \mu \mathrm{g} / \mathrm{dL}$ in metropolitan Tehran to investigate possible environmental risk factors in their home. Household specimens including scratched wall paint, house floor dust, windowsill dust, tap water, and consumed spice were evaluated using atomic absorption method to detect lead concentrations. Epidemiological and environmental data collected through in-depth interviews with parents/guardians. Industrial areas were defined based on municipality maps on industrial places.

Results: Thirty of 56 parents/guardians with BLL $>5 \mu \mathrm{g} / \mathrm{dL}$ agreed to be followed through environmental investigation. The only categorical statistically significant risk factor was a history of lead poisoning in the family and living in an industrial zone. There was a positive correlation between BLL and interior windowsills dust lead level, $r=0.46, p=0.01$. Scratched paint lead level and BLL showed a significant positive correlation, $r=0.50, p=0.005$. House floor dust lead level (median $=77.4, p<0.001$ ) and interior windowsill dust lead level (median $=291, p=$ 0.011 ) were both significantly higher than the environmental protection agency (EPA) standards of $40 \mu \mathrm{g} / \mathrm{ft}^{2}$, $250 \mu \mathrm{g} / \mathrm{ft}^{2}$. Interior windowsill dust lead concentrations were significantly higher in industrial areas $(p=0.026)$.

Conclusion: Children's playing environment should be cleaned more often to reduce dust. Moreover, specific rules may need to be implemented for paint lead concentrations and air pollution, especially in industrial areas.
\end{abstract}

Keywords: Lead toxicity, Children, Trace elements, Plumbism

\footnotetext{
* Correspondence: hassanian@sbmu.ac.ir

${ }^{5}$ Social Determinants of Health Research Center, Shahid Beheshti University of Medical Sciences, Tehran, Iran

${ }^{6}$ Department of Clinical Toxicology, Loghman Hakim Hospital, School of Medicine, Shahid Beheshti University of Medical Sciences, South Karegar Street, Tehran, Iran

Full list of author information is available at the end of the article
}

(c) The Author(s). 2021 Open Access This article is licensed under a Creative Commons Attribution 4.0 International License, which permits use, sharing, adaptation, distribution and reproduction in any medium or format, as long as you give appropriate credit to the original author(s) and the source, provide a link to the Creative Commons licence, and indicate if changes were made. The images or other third party material in this article are included in the article's Creative Commons licence, unless indicated otherwise in a credit line to the material. If material is not included in the article's Creative Commons licence and your intended use is not permitted by statutory regulation or exceeds the permitted use, you will need to obtain permission directly from the copyright holder. To view a copy of this licence, visit http://creativecommons.org/licenses/by/4.0/ The Creative Commons Public Domain Dedication waiver (http://creativecommons.org/publicdomain/zero/1.0/) applies to the data made available in this article, unless otherwise stated in a credit line to the data. 


\section{Background}

The physical properties of lead allow this metal to be used in many industrial applications [1]. However, lead has numerous detrimental effects on several organ systems, most notably the nervous system [2]. For years, lead has been utilized in various industries and products leading to higher contact and higher poisoning rates [3]. Lead toxicity is a worldwide public health hazard. There is no completely safe blood lead level (BLL) to date even $5 \mu \mathrm{g} / \mathrm{dL}$ - and damage may occur at low BLL $[4,5]$. Even though developed countries promoted environmental regulations to lower lead poisoning rates, developing countries still represent high rates of lead toxicity, especially in the children [6].

Ingestion and inhalation are the most common routes for lead absorption [7]. In addition to occupational and environmental exposures, drinking water, food [8], spices, traditional medicine, acidic canned foods in lead-soldered containers are the most common foods contaminated with lead [9-11]. Older water pipes and other water infrastructures release lead into the water $[12,13]$. Water treatment procedures and changing the water source are other reasons for water lead contamination $[14,15]$.

Household dust [16]; decayed paints, soil dust near roads or industrial areas, lead-glazed ceramics, home remedies, cookware and air pollutants are probable house dust sources [17]. Urbanized residential topsoil show about 7 times higher lead concentration. There are difference between sampling locations and the highest attributed to dripline at the same area [18]. Lead remains in topsoil for even centuries and its redistribution exposes people to higher toxicity risk [19].

Lead affects almost all organ systems in the body, including the nervous, digestive, renal, and hematopoietic systems [20, 21]. Lead toxicity is mostly without any signs or symptoms. The most common signs or symptoms are constipation, abdominal pain, anemia, fatigue, weakness, irritability, renal dysfunction, and neuropathies [2, 21]. Neurological symptoms like learning impairment, irritability, attention-deficit/ hyperactive disorder, and lower IQ scores are identified in children who may also have poor socio-economic support, reinforcing the importance of lead poisoning [22-25].

Children may absorb proportionally more lead than adults and excrete less lead in urine [26, 27]. Children crawl on the floor, have hand-to-mouth and pica behaviors, all of which make them at higher risk of exposure to lead [28]. After knowing more about lead's adverse effect on children's developing brain, a couple of regulations are implemented to decrease lead exposure. Governments phased out leaded gasoline, defined limits for maximum lead in paints, and drinking water [2931]. In Iran, leaded gasoline was eliminated in 2000.
With lead removal from petrol, there has been a sustained decline followed by a plateau.

Studies on probable risk factors of lead poisoning in Iranian children are insufficient. In this study, we aimed to evaluate possible environmental factors in children with high BLLs living in Tehran and neighboring cities.

\section{Methods \\ Study design \& settings}

This cross-sectional study includes children referred from two pediatric gastrointestinal clinics with $\mathrm{BLL}>5 \mu \mathrm{g} / \mathrm{dL}$ in Tehran between March 2018 and March 2019.

\section{Sample size and participants}

A previous study at one of two workplaces showed a $\mathrm{BLL}>5 \mu \mathrm{g} / \mathrm{dL}$ in $25 \%$ of referral patients to pediatric clinic [32]. The following formula is used to calculate the size of the required sample:

$$
\mathrm{n}=(\mathrm{z}) 2 \mathrm{p}(1-\mathrm{p}) / \mathrm{d} 2
$$

Considering 95\% confidence interval $(\mathrm{z}=1.96)$ and tolerated margin of error equal to 0.5 , the required sample size was 289 cases. These participants were chosen based on a convenience sampling from all pediatric population that referred due to abdominal pain and/or constipation to gastroenterology clinics. Inclusion criteria were defined as 1- BLLs higher than $5 \mu \mathrm{g} / \mathrm{dL}$. 2- Agreeing to participate in an interview and allowing essential lab studies. 3- Agreeing to allow environmental investigations including sampling in the home. The only exclusion criterion was parents (guardians) unwillingness to participate in the study. Figure 1 shows the flowchart of recruitment.

Patients were tested for BLL by voltammetry method. Patients with BLLs higher than $5 \mu \mathrm{g} / \mathrm{dL}$ were included in the final environmental evaluation of measuring household specimens lead concentrations with atomic absorption method.

\section{Variables}

Parents reported demographic data (Supplementary questionnaire). Stature-for age were calculated and categorized based on WHO child growth standards. BMIfor-age were calculated and categorized based on WHO growth reference charts and tables. For children under 5 years of age: overweight is defined as weight-for-height greater than 2 standard deviations (SD) above WHO Child Growth Standards median; and obesity is defined as weight-for-height greater than $3 \mathrm{SD}$ above the WHO Child Growth Standards median. For between 5 and 19 years children, overweight is defined as BMI-for-age greater than $1 \mathrm{SD}$ above the WHO Growth Reference median; and obesity is defined as greater than $2 \mathrm{SD}$ 


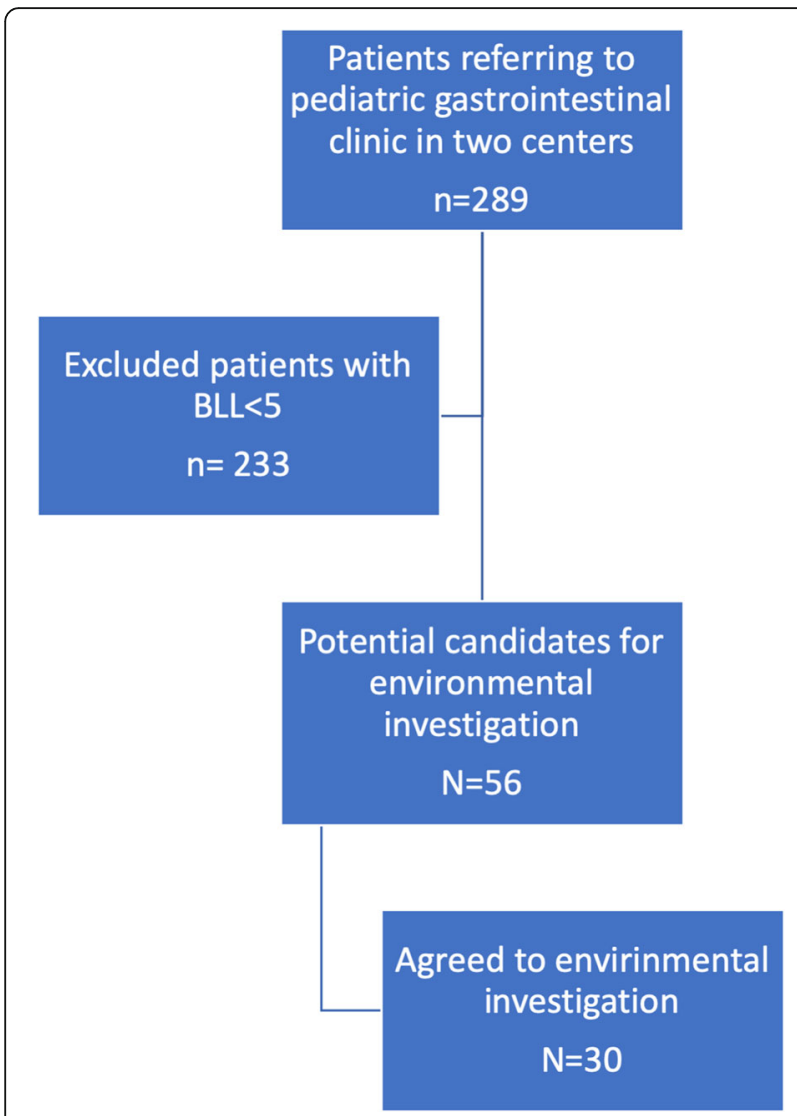

Fig. 1 Flowchart of selecting patients for environmental assessments

above the WHO Growth Reference median [33]. Parents were asked about children age, restlessness history, living in an area known as industrial, history of lead poisoning in family, pica, house age, residence in house duration, water pipe material and age, tap material and age, recent house painting, and consuming excessive spice compared to relatives and friends. Environmental samples were gathered to measure their lead concentrations by atomic absorption method.

\section{Sampling \& measurement}

To evaluate environmental factors, scratched wall paint, house floor dust, windowsills' dust, tap water, and consumable spice with lead contamination were evaluated.

Wall paint specimen, scratched by a stainless steel scalpel in four different places where the child spends more time, was obtained [34]. Scratched paints were stored in a plastic bag in $4{ }^{\circ} \mathrm{C}$ until lead level measurement. One gram of paint was dissolved in $5 \mathrm{~mL}$ nitric acid and $15 \mathrm{~mL}$ hydrochloric acid (aqua regia) to measure the paint lead level. Then the solution was kept 30 min in room temperature under hood. Then it was kept in a heater with a temperature of $50^{\circ} \mathrm{C}$ for $30 \mathrm{~min}$. After that, the solution was cooled to reach room temperature.
The solution was filtered using Whatman filtration paper. Finally, lead concentrations were measured by graphite furnace atomic absorption spectrometry (GFAA S) method with Agilent Technologies GTA120 Graphite Tube Atomizer device [34].

Two places in which the child spends the most time were evaluated for the dust lead level. Floor dust was sampled by wiping a one-foot square area of the house floor with a wet wipe. We wiped the surface with an Sshaped pattern to ensure a complete cleaning. The process was repeated for one more time, and the specimen was stored at $4{ }^{\circ} \mathrm{C}$ until evaluation for lead level. Then one gram of the wet wipe dissolved in aqua regia; the remaining procedure is the same as for scratched paint [35].

Child's room windowsills dust obtained from an area of $100 \mathrm{~cm}^{2}$ ( 2 by $8 \mathrm{in}$.). Dust wiped by a wet wipe in a linear direction three times on the targeted area. All other procedure parts are the same as floor dust evaluation [35].

The most frequently used self-reported spice in each family in cooking were sampled in each house to measure lead concentrations. To measure spice lead concentrations, one gram of spice was dissolved in aqua regia, as previous specimens. The same method was used to measure spice lead concentrations. Tap water was sampled for measuring household consuming water lead level. The water lead level is directly measured using atomic absorption method.

\section{Statistical analysis}

We stratified the demographic characteristics and investigated differences in their BLLs. Due to the violation of normality assumptions (based on Shapiro wilk test and generated Q-Q plot) in BLLs, we performed MannWhitney and Kruskal Walis test to determine the relation between BLLs and demographic characteristics as probable risk factors. Pearson's correlation was performed to evaluate the relation between continuous data and BLL. All univariate analyses which showed a $P<$ 0.05 were included in the final fitted multivariate regression model to quantify the relationship between them and BLL. A $p<0.05$ considered significant in the final analysis. One sample Wilcoxon signed-rank tests were conducted to compare paint lead, water lead level, surface dust lead level, and interior windowsill with international standards.

\section{Results}

During the study period, 56 cases with $\mathrm{BLL}>5 \mu \mathrm{g} / \mathrm{dL}$ from two different pediatric gastrointestinal clinics referred for environmental follow-up. Of whom 30 (53.6\%) agreed to be followed through environmental investigation. Figure 2 depicts the geolocations of study subjects 


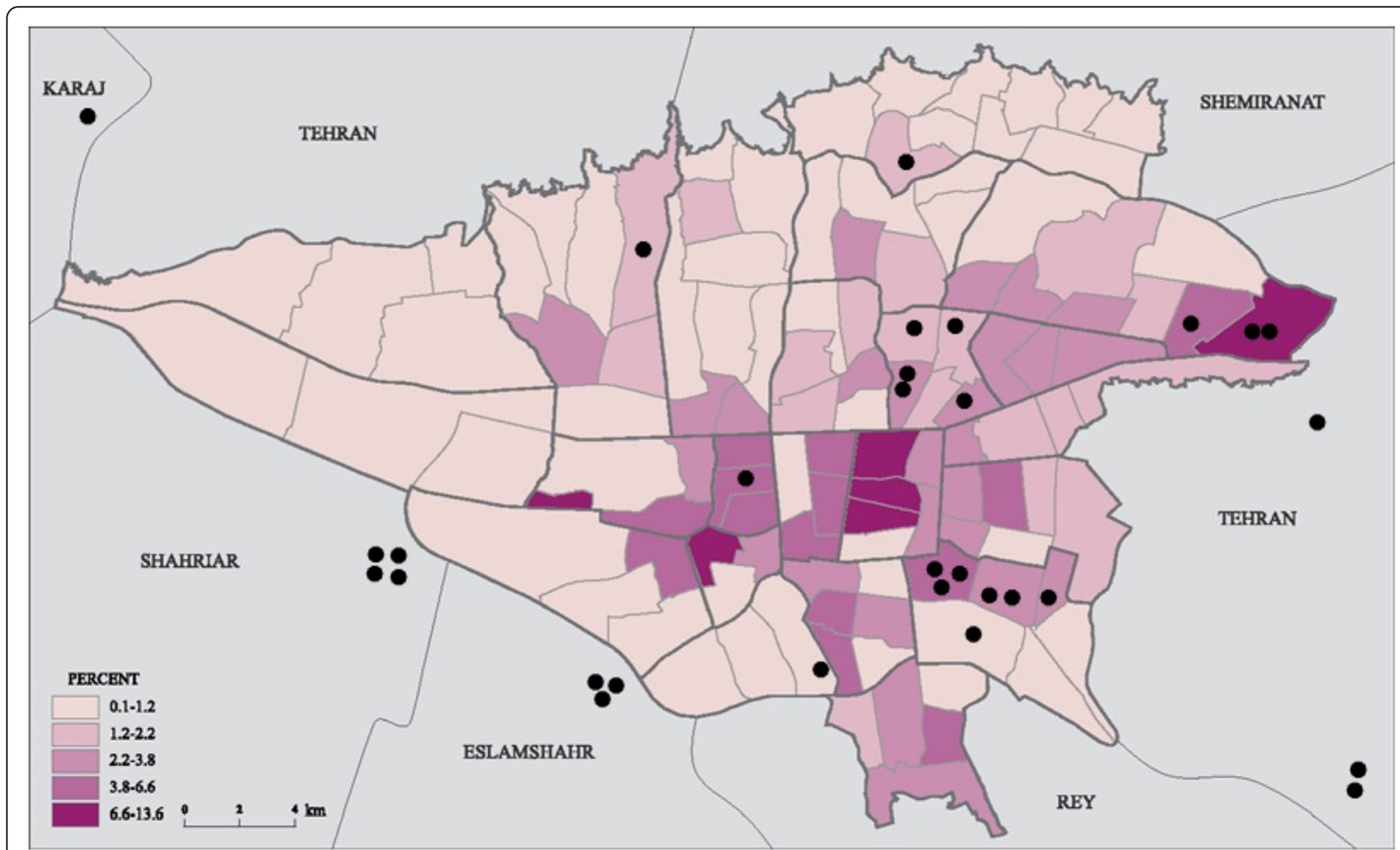

Fig. 2 Tehran Geo-mapping industrial districts and referral pediatric patients (Industrial zones are retrieved from Tehran Municipality map: https://atlas.tehran.ir/Default.aspx?tabid=318)

living locations in Tehran, with considering adjacent industrial districts.

The final participants' mean age was 6.1 years $(\mathrm{SD}=$ 3.1, range 1-13 years). Participants' BLL based on their characteristics are presented in Table 1 and Table 2. The only categorical statistically significant risk factor was a history of lead poisoning in the family and living in an industrial zone.

Median (IQR) of BLL, tap water lead, interior windowsills dust lead, house ground dust lead, scratched paint lead, spice lead concentrations are presented in Table 3.

There was a positive correlation between BLL and interior windowsills dust lead level, $r=0.46, p=0.01$ (Fig. 3). Scratched paint lead level and BLL showed a significant positive correlation, $r=0.50, p=0.005$ (Fig. 4). No correlation was observed between BLL and participants age $(p=0.9)$, weight $(p=0.7)$ building age $(p=0.2)$, pipe age $(p=0.2)$, water lead $(p=0.7)$, house floor lead $(p=0.8)$, BMI, $(p=0.7)$, and spice lead $(p=0.5)$.

An adjusted multivariate linear regression was calculated to predict participants' BLL. A variable that showed a significant difference in BLLs in univariate analysis was included in the model; interior window-sills dust lead level, scratched paint lead level, history of lead poisoning in family members, and residence in industrial area were included in the model. A significant regression equation was found $(\mathrm{F}(5,24)=4.154, p<0.01)$, with an $\mathrm{R}^{2}$ of 0.464 .

The paint lead's median was not significantly different from the recommended limit of $90 \mathrm{ppm}$ by the U.S. Consumer Product Safety Commission (CPSC) (median $=105.6, p=0.28$ ). However, house floor dust lead level (median $=77.4, p<0.001$ ) and interior window-sill dust lead level (median $=291, p<0.001$ ) were both significantly higher than the environmental protection agency (EPA) standards of $40 \mu \mathrm{g} / \mathrm{ft}^{2}, 250 \mu \mathrm{g} / \mathrm{ft}^{2}$. Interior window-sill dust lead concentrations were significantly higher in industrial areas $(p=0.026)$.

We compared environmental lead concentrations with corresponding international standards (Table 4).

\section{Discussion}

This study aimed to identify the responsible sources of lead exposure in children in Tehran, Iran, referred from pediatric gastrointestinal clinics. CDC mentions that lead-based paint and lead-containing dust are the most common and dangerous lead poisoning sources in young children [36]. Our key findings showed that scratched paint lead concentrations and interior windowsills lead concentrations correlate with children's elevated BLL. 
Table 1 Demographic and clinical characteristics

\begin{tabular}{|c|c|c|c|c|}
\hline \multicolumn{2}{|c|}{ Demographic and clinical characteristics } & \multirow{2}{*}{$\frac{\mathbf{N}}{19}$} & \multirow{2}{*}{$\frac{\text { Median BLL (IQR) }}{8.9(6.2-24)}$} & \multirow{2}{*}{$\frac{P \text {-value }}{0.698}$} \\
\hline Sex & $\mathrm{F}$ & & & \\
\hline & M & 11 & $6.9(5.5-25$ & \\
\hline \multirow[t]{3}{*}{ Age } & $<4 y$ & 11 & $6.9(5.9-30.6)$ & 0.842 \\
\hline & $4-7$ y & 6 & $11(6.4-19.1)$ & \\
\hline & $>7 y$ & 13 & $8.9(5.3-23.6)$ & \\
\hline \multirow[t]{3}{*}{ Stature-age } & Severely stunted & 2 & $7.2(\mathrm{NA})$ & 0.295 \\
\hline & stunted & 1 & $30.6(N A)$ & \\
\hline & Normal & 27 & $8.9(5.5-24)$ & \\
\hline \multirow[t]{5}{*}{ BMl-age } & Severely underweight & 1 & $5.3(\mathrm{NA})$ & 0.71 \\
\hline & Underweight & 6 & $5.8(5.1-6.8)$ & \\
\hline & Normal & 17 & $12.9(6.5-26.3)$ & \\
\hline & Moderately overweight & 3 & $23.2(\mathrm{NA})$ & \\
\hline & Overweight & 3 & $9.2(\mathrm{NA})$ & \\
\hline \multirow[t]{2}{*}{ Pica } & no & 23 & $8.5(5.9-25)$ & 0.787 \\
\hline & yes & 5 & $23.2(5.3-27.5)$ & \\
\hline \multirow[t]{2}{*}{ Food allergy } & no & 25 & $8.5(5.5-20.2)$ & 0.277 \\
\hline & yes & 5 & $23.2(6.2-45.3)$ & \\
\hline \multirow[t]{2}{*}{ Restlessness } & no & 28 & $8.7(5.9-23.8)$ & 1 \\
\hline & yes & 2 & $25(\mathrm{NA})$ & \\
\hline \multirow[t]{2}{*}{ Family history of lead poisoning } & no & 25 & $6.9(5.5-14)$ & 0.008 \\
\hline & yes & 5 & $27.1(20.2-29.7)$ & \\
\hline \multirow[t]{2}{*}{ Addiction in father } & no & 25 & $6.9(5.7-24.5)$ & 0.867 \\
\hline & yes & 5 & $8.9(6.8-21.7)$ & \\
\hline
\end{tabular}

Lead concentrations in windowsills dust were significantly higher in participants living in industrial areas.

Until recently, windows in Iranian buildings were not appropriately sealed due to low energy prices [37]. Unsealed windows may pass higher amounts of dust originating directly from polluted air or redistribution of topsoil containing lead [38]. Topsoil lead is a major contributor to childhood lead exposure especially in droughty times [39]. Interior windowsill dust may represent outside rather than inside sources such as leaded paint used on sliding window frames. Our results demonstrated that windowsill dust was the most correlated factor with elevated BLL. Those are in line with Zamani et al. findings that revealed residence in an industrial area with a polluted atmosphere might increase lead poisoning risk. However, in their study, contrary to our results, pipe type and materials affected children's BLLs [32].

Leaded gasoline as a renowned environmental pollutant phased-out years ago in Iran [32], and atmosphere lead pollution probably originate from other sources like particles emitted from tires, brakes, metal equipment in industrial areas [40]. The roads may matter as this is airborne from auto exhaust but also fine particles on dust again from exhaust that re-entrains on dust and is inhaled or even ingested plus the lead tends to accumulate on floors, yards etc. where children may play, especially children still crawling and have hand to mouth behavior, in ages $<18-24$ months. In Iran, children usually start schooling at age six. We could not find any statistical difference between children at schooling years vs. below schooling year. Facing more elevated BLL at higher ages this suggests a different source than soil/dust (i.e., maybe water (pipes), possibly food but more commonly it is an active air source from somewhere- mainly roads and industrial processes.

A few years ago, cars used leaded gasoline and released large amounts of lead into the air. Released lead finally settled on the city ground; redistribution of settled lead into the air might be another source of air lead pollution entering houses through windows [37, 41]. Moreover, Taghavi et al. analyzed streets' dust lead concentrations a few years after phasing out leaded gasoline. They showed that Tehran streets are moderately polluted by lead based on the geoaccumulation index $(3<$ Enrichment Factor $(\mathrm{EF}) \leq 5$; Mean $\mathrm{pb}=110.27)$ [40]. 
Table 2 Environmental characteristics

\begin{tabular}{|c|c|c|c|c|}
\hline Environmental characteristics & & $\mathbf{N}$ & Median BLL (IQR) & $P$-value \\
\hline \multirow[t]{2}{*}{ Reconstruction in 6 month } & no & 29 & $8.5(5.7-23.6)$ & 0.326 \\
\hline & yes & 1 & $25(\mathrm{NA})$ & \\
\hline \multirow[t]{2}{*}{ Building painting in 6 month } & no & 26 & $8.7(5.8-23.6)$ & 0.807 \\
\hline & yes & 4 & $15.1(5.5-28.9)$ & \\
\hline \multirow[t]{2}{*}{ Industrial zone } & no & 15 & $6.2(5.3-12.9)$ & 0.038 \\
\hline & yes & 15 & $16.4(6.8-27.1)$ & \\
\hline \multirow[t]{2}{*}{ Building's paint type } & Oil & 26 & $8.8(5.8-24.2)$ & 0.737 \\
\hline & Plastic (acrylic) & 4 & $7.5(5.3-25.1)$ & \\
\hline \multirow[t]{3}{*}{ Building's Pipe material } & Metal & 14 & $12.1(6-25.9)$ & 0.352 \\
\hline & Non-metal & 15 & $6.8(5.5-12.9)$ & \\
\hline & both & 1 & $25(\mathrm{NA})$ & \\
\hline \multirow[t]{3}{*}{ Habit of excessive Spice consumption in family } & No & 28 & $9(5.9-24.7)$ & 0.157 \\
\hline & Yes & 2 & $5.7(\mathrm{NA})$ & \\
\hline & both & 1 & $25(\mathrm{NA})$ & \\
\hline \multirow[t]{3}{*}{ Spice Packaging } & Hygiene Pack & 6 & $24.1(6.7-26.9)$ & 0.280 \\
\hline & Bulk-sale & 16 & $7.9(5.6-14.5)$ & \\
\hline & Both & 8 & 7.6 (5.2-28.9) & \\
\hline \multirow[t]{3}{*}{ Residence duration } & $0-3$ y & 18 & $8.7(6.1-24.4)$ & 0.990 \\
\hline & $4-6 y$ & 5 & $6.2(5.5-44.1)$ & \\
\hline & $>7 y$ & 7 & $11.2(5.2-25)$ & \\
\hline
\end{tabular}

House paint lead concentrations were marginally correlated with participants' BLL. However, paint lead concentrations in our study were not significantly higher than the CPSC standard of $90 \mathrm{ppm}$ [40]. We hypothesized that it might be due to the lower quality of paints in Iran, which results in higher rates of peeling and cracking. All of which results in more lead paint chips and dust, making children susceptible to lead poisoning even if the paint's lead did not exceed international standards. Paint lead concentrations usually were correlated to children's BLLs in conducted studies on this matter that is in line with our results $[16,26]$. Recent painting and reconstruction showed no significant effect on children's BLLs.

Even though the measured house floor's dust lead concentrations were significantly higher than EPA standards [42], they were not significantly correlated with elevated BLLs. Children crawling on the floor are the most incontact to floor dust lead ingestion and poisoning [43]. Participants in our study were older than 1 year and probably able to walk and crawl less on the floor. So, despite high lead concentrations of floor dust, it was not correlated to BLLs.

Spice lead concentrations were not higher than WHO standards [44] and were not correlated to BLLs. Both of which reinforces the unlikelihood of spice-induced lead poisoning. Our results on the Tehran water lead level, were in accordance with previous Iranian studies, and suggest that Tehran tap water contains more lead than EPA standard [45-48]. However, it was not correlated with higher BLLs. Higher BLLs were not related to having more food sensitization which is in accordance with Mener's results that showed no significant change in food allergic sensitization rates in children with high BLLs unlike adults [49].

Lead poisoning has irreversible effects on brain development and children's height leading to high burdens on health systems $[15,25,50,51]$. We did not notice a significant decrease in participant's height and mental function. However, 2 had hyperactivity disorder.

Table 3 Specimens lead level

\begin{tabular}{|c|c|c|c|c|c|c|}
\hline Lead level & $\begin{array}{l}\text { Blood }(\mu \mathrm{g} / \\
\mathrm{dL})\end{array}$ & $\begin{array}{l}\text { Tap water }(\mu \mathrm{g} / \\
\mathrm{L})\end{array}$ & $\begin{array}{l}\text { Interior windowsill dust }(\mu \mathrm{g} / \\
\mathrm{ft} 2 \text { ) }\end{array}$ & $\begin{array}{l}\text { House ground dust }(\mu \mathrm{g} / \\
\mathrm{ft} 2)\end{array}$ & $\begin{array}{l}\text { Scratched paint } \\
\text { (ppm) }\end{array}$ & Spice $(\mu \mathrm{g} / \mathrm{Kg})$ \\
\hline $\begin{array}{l}\text { Median } \\
\left(\mid \mathrm{QR}^{\mathrm{a}}\right)\end{array}$ & $8.7(5.8-24.2)$ & $63.5(36-78.9)$ & $291(231.2-345.2)$ & $77.4(66.4-84)$ & $105.6(71.1-123.7)$ & $\begin{array}{l}\text { and } 56.7(20.6- \\
98.5)\end{array}$ \\
\hline
\end{tabular}

${ }^{\mathrm{a}} \mathrm{QR}$ interquartile range 


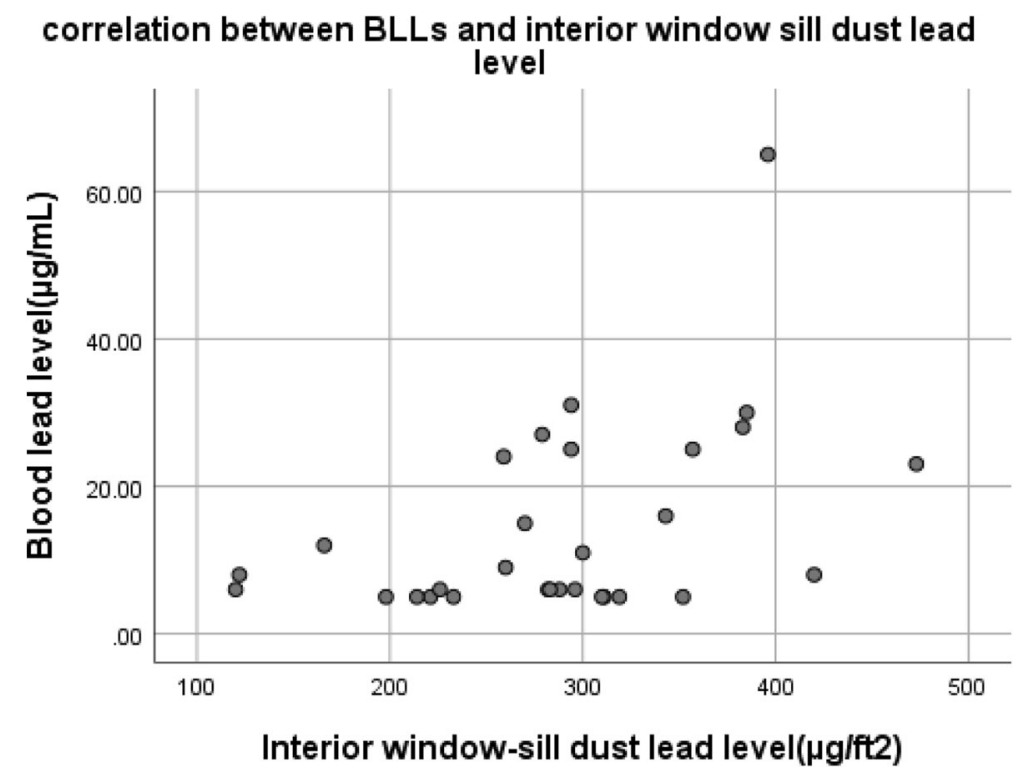

Fig. 3 Correlation between BLL and interior window-sill dust lead level

Geo-mapping is helpful to find lead hot spots for cleanup or further cases of lead poisoning. We were not able to do soil mapping but could define industrial districts on a simple map to look at patterns of exposure.

\section{Conclusion}

To avoid the burden of lead poisoning, parents should be informed about the most common reasons and sources of poisoning; children's laying environment should be cleaned more often to reduce dust. Moreover, specific rules should be implemented about paint lead concentrations and air pollution, especially in industrial areas.

\section{Limitations}

Our study's most significant limitation was sample size; lead poisoning is not highly prevalent in Tehran, making it more difficult to recruit more participants who accept

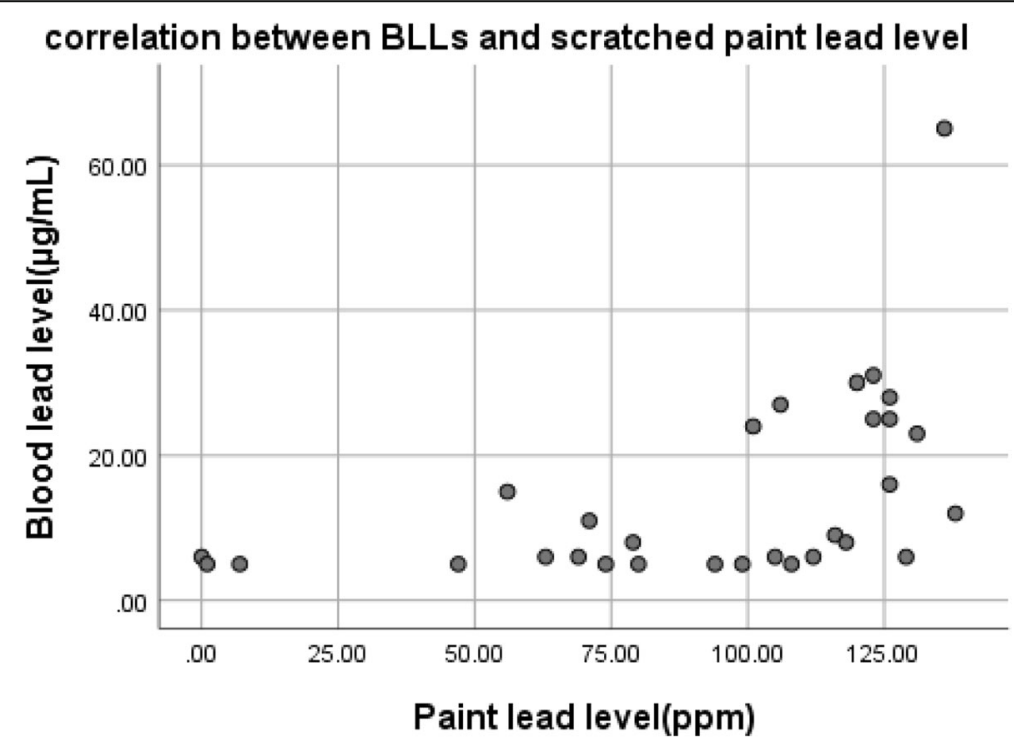

Fig. 4 Correlation between BLL and scratched paint lead level 
Table 4 Lead concentrations compared with international standards

\begin{tabular}{llll}
\hline Lead level & Median $($ IQR) & Standard limit & $p$-value \\
\hline Scratched paint $(\mathrm{ppm})$ & $105.6(71.1-123.7)$ & $90\left(\mathrm{CPSC}^{\mathrm{a}}\right)$ & 0.28 \\
House floor dust $\left(\mu \mathrm{g} / \mathrm{ft}^{2}\right)$ & $77.4(66.5-84)$ & $10\left(\mathrm{EPA}^{\mathrm{b}}\right)$ & $<0.001$ \\
Interior window-sills dust $\left(\mu \mathrm{g} / \mathrm{ft}^{2}\right)$ & $291(231.2-345.2)$ & $100\left(\mathrm{EPA}^{\mathrm{b}}\right)$ & $<0.001$ \\
Tap water $(\mu \mathrm{g} / \mathrm{kg})$ & $63.5(36-78.9)$ & $15\left(\mathrm{EPA}^{\mathrm{b}}\right)$ & $<0.001$ \\
Spice $(\mu \mathrm{g} / \mathrm{kg})$ & $56.7(20.6-98.5)$ & $300\left(\mathrm{WHO}^{\mathrm{c}}\right)$ & $<0.001$ \\
\hline
\end{tabular}

${ }^{a}$ Consumer product safety commission

${ }^{\mathrm{b}}$ Environmental protection agency

c World health organization

to be assessed in the environment. We suggest that researchers conduct multicenter studies with bigger sample sizes. A major limitation is the lack of soil $\mathrm{Pb}$ results in the neighborhoods of the industrial zone compare to the other parts of the city. This could yield important information about the source of $\mathrm{Pb}$ dust in Tehran. Another limitation is the lack of a control group in this study. So, we were not able to investigate the kids' environment with normal BLL.

We suggest performing another study including a control group to develop more robust results.

\section{Abbreviations}

BLL: Blood lead level; CDC: Center for disease control; CPSC: Consumer Product Safety Commission; EPA: Environmental Protection Agency; GFAA S: Graphite furnace atomic absorption spectrometry; WHO: World health organization

\section{Supplementary Information}

The online version contains supplementary material available at https:/doi. org/10.1186/s12889-021-11494-1.

Additional file 1. Environmental lead assessment questionnaire.

\section{Acknowledgments}

This study was done through thesis of Ms. Afsoon Karimdoost and Ms. Hedieh Ahangar.

\section{Authors' contributions}

AAK, NZ, MA and HHM participated in the study design. AK, HA, HHM and $\mathrm{NH}$ participated in the acquisition and interpretation of all data. AS wrote the first draft of manuscript. NZ, SP, GRK and HHM critically revised the manuscript. All the authors have read the journal's authorship agreement and the manuscript has been reviewed by and approved by all named authors.

\section{Funding}

This study was funded by Shahid Beheshti University of Medical Sciences, Tehran, Iran. The funding body played no role in the design of the study and collection, analysis, and interpretation of data and in writing the manuscript.

\section{Availability of data and materials}

The datasets used during the current study available from the corresponding author on reasonable request.

\section{Declarations}

\section{Ethics approval and consent to participate}

All procedures performed in this study was in accordance with the ethical standards of the institutional and national research committee and with the 1964 Helsinki Declaration and its later amendments or comparable ethical standards. The study was approved by the Ethics Committee of Shahid Beheshti University of Medical Sciences, Tehran, Iran (IR.SBMU.RETECH.REC.1397.556). Written informed consent was obtained from all parents/guardians of all minor participants included in the study at interview time.

\section{Consent for publication}

Not applicable.

\section{Competing interests}

Not applicable.

\section{Author details}

${ }^{1}$ Pharmaceutical Sciences Branch, Islamic Azad University (IAUPS), Tehran, Iran. ${ }^{2}$ School of Medicine, Shahid Beheshti University of Medical Sciences, Tehran, Iran. ${ }^{3}$ Legal Medicine Research Center, Iranian Legal Medicine Organization, Tehran, Iran. ${ }^{4}$ University of Colorado Anchutz Medical Campus, Rocky Mountain Poison \& Drug Safety, Denver, CO and Washington Poison Center, Seattle, WA, USA. ${ }^{5}$ Social Determinants of Health Research Center, Shahid Beheshti University of Medical Sciences, Tehran, Iran. ${ }^{6}$ Department of Clinical Toxicology, Loghman Hakim Hospital, School of Medicine, Shahid Beheshti University of Medical Sciences, South Karegar Street, Tehran, Iran. ${ }^{7}$ Skaggs School of Pharmacy and Pharmaceutical Science, University of Colorado Anschutz Medical Campus, Aurora, CO 80045, USA.

Received: 13 December 2020 Accepted: 12 July 2021

Published online: 21 July 2021

\section{References}

1. Flora G, Gupta D, Tiwari A. Toxicity of lead: a review with recent updates. Interdiscip Toxicol. 2012;5(2):47-58. https://doi.org/10.2478/v10102-0120009-2.

2. Wani AL, Ara A, Usmani JA. Lead toxicity: a review. Interdiscip Toxicol. 2015; 8(2):55-64. https://doi.org/10.1515/intox-2015-0009.

3. Hayatbakhsh MM, et al. Lead poisoning among opium users in Iran: an emerging health hazard. Subst Abuse Treat Prev Policy. 2017:12(1):43.

4. Betts KS. CDC updates guidelines for children's lead exposure. Environ Health Perspect. 2012;120(7):a268. https://doi.org/10.1289/ehp.120-a268.

5. Gao Z, et al. Blood Lead levels and risk factors among preschool children in a Lead polluted area in Taizhou, China. Biomed Res Int. 2017;2017:4934198.

6. Kordas K, Ravenscroft J, Cao Y, McLean EV. Lead exposure in low and middle-income countries: perspectives and lessons on patterns, injustices, economics, and politics. Int J Environ Res Public Health. 2018;15(11):2351. https://doi.org/10.3390/ijerph15112351.

7. Karrari P, Mehrpour O, Abdollahi M. A systematic review on status of lead pollution and toxicity in Iran; guidance for preventive measures. Daru. 2012; 20(1):2. https://doi.org/10.1186/1560-8115-20-2.

8. Frank JJ, Poulakos AG, Tornero-Velez R, Xue J. Systematic review and meta-analyses of lead $(\mathrm{Pb})$ concentrations in environmental media (soil, dust, water, food, and air) reported in the United States from 1996 to 2016. Sci Total Environ. 2019;694:133489. https://doi.org/10.1016/j. scitotenv.2019.07.295

9. Wang M, Liang B, Zhang W, Chen K, Zhang Y, Zhou H, et al. Dietary Lead exposure and associated health risks in Guangzhou, China. Int J Environ Res Public Health. 2019;16(8):1417. https://doi.org/10.3390/ijerph16081417. 
10. Lin CG, Schaider LA, Brabander DJ, Woolf AD. Pediatric lead exposure from imported Indian spices and cultural powders. Pediatrics. 2010;125(4):e82835. https://doi.org/10.1542/peds.2009-1396.

11. Al Zabadi H, Sayeh G, Jodeh S. Environmental exposure assessment of cadmium, lead, copper and zinc in different Palestinian canned foods. Agric Food Secur. 2018:7(1):50.

12. Lindquist DM, Beckwith T, Cecil KM, Sánchez-Martín FJ, Landero-Figueroa J, Puga A. Prenatal and early postnatal lead exposure in mice: neuroimaging findings. Quantitative imaging in medicine and surgery. 2015;5(4):511-8. https://doi.org/10.3978/j.issn.2223-4292.2015.07.01.

13. Chandran L, Cataldo R. Lead poisoning: basics and new developments. Pediatr Rev. 2010;31(10):399-405; quiz 406. https://doi.org/10.1542/pir.31-10-399.

14. DeWitt RD. Pediatric lead exposure and the water crisis in Flint, Michigan. Jaapa. 2017;30(2):43-6. https://doi.org/10.1097/01.JAA.0000511794.60054.eb.

15. Hanna-Attisha M, LaChance J, Sadler RC, Champney Schnepp A. Elevated blood Lead levels in children associated with the Flint drinking water crisis: a spatial analysis of risk and public health response. Am J Public Health. 2016;106(2):283-90. https://doi.org/10.2105/AJPH.2015.303003.

16. Lanphear BP, Weitzman M, Winter NL, Eberly S, Yakir B, Tanner M, et al. Lead-contaminated house dust and urban children's blood lead levels. Am J Public Health. 1996;86(10):1416-21. https://doi.org/10.2105/AJPH.86.10.1416.

17. Dignam T, Pomales A, Werner $L$, Newbern EC, Hodge J, Nielsen J, et al. Assessment of child Lead exposure in a Philadelphia community, 2014. J Public Health Manag Pract. 2019;25(1):53-61. https://doi.org/10.1097/PHH. 0000000000000711.

18. Obeng-Gyasi E, Roostaei J, Gibson JM. Lead distribution in urban soil in a medium-Sized City: household-scale analysis. Environ Sci Technol. 2021; 55(6):3696-705. https://doi.org/10.1021/acs.est.0c07317.

19. Filippelli GM, et al. Mapping the urban lead exposome: a detailed analysis of soil metal concentrations at the household scale using citizen science. Int J Environ Res Public Health. 2018;15(7):1531.

20. Mărginean CO, Melit LE, Moldovan H, Lupu W, Mărginean MO. Lead poisoning in a 16-year-old girl: a case report and a review of the literature (CARE compliant). Medicine (Baltimore). 2016;95(38):e4916. https://doi.org/1 0.1097/MD.0000000000004916.

21. Sadeghniiat-Haghighi K, Saraie M, Ghasemi M, Izadi N, Chavoshi F, Khajehmehrizi A. Assessment of peripheral neuropathy in male hospitalized patients with lead toxicity in Iran. J Res Med Sci. 2013:18(1):6-9.

22. Mason LH, Harp JP, Han DY. Pb neurotoxicity: neuropsychological effects of lead toxicity. Biomed Res Int. 2014;2014:840547.

23. Lidsky TI, Schneider JS. Lead neurotoxicity in children: basic mechanisms and clinical correlates. Brain. 2003;126(1):5-19. https://doi.org/10.1093/bra in/awg014.

24. Daneshparvar M, Mostafavi SA, Jeddi MZ, Yunesian M, Mesdaghinia A, Mahvi AH, et al. The role of lead exposure on attention-deficit/hyperactivity disorder in children: a systematic review. Iran J Psychiatry. 2016;11(1):1-14.

25. Carpenter C, Potts B, von Oettingen J, Bonnell R, Sainvil M, Lorgeat V, et al Elevated blood Lead levels in infants and children in Haiti, 2015. Public Health Rep. 2019;134(1):47-56. https://doi.org/10.1177/0033354918807975.

26. Safruk AM, MCGregor E, Whitfield Aslund ML, Cheung PH, Pinsent C, Jackson $\mathrm{BJ}$, et al. The influence of lead content in drinking water, household dust, soil, and paint on blood lead levels of children in Flin Flon, Manitoba and Creighton, Saskatchewan. Sci Total Environ. 2017;593-594:202-10. https:// doi.org/10.1016/j.scitotenv.2017.03.141.

27. Health-Canada. Final Human Health State of the Science Report on Lead. 2013 [cited 202021 September]; Available from: https://www.canada.ca/en/ health-canada/services/environmental-workplace-health/reports-publica tions/environmental-contaminants/final-human-health-state-science-reportlead.html.

28. Schnur J, John RM. Childhood lead poisoning and the new Centers for Disease Control and Prevention guidelines for lead exposure. J Am Assoc Nurse Pract. 2014;26(5):238-47. https://doi.org/10.1002/2327-6924.12112.

29. Weitzman M. Blood Lead screening and the ongoing challenge of preventing Children's exposure to Lead. JAMA Pediatr. 2019;173(6):517-9. https://doi.org/10.1001/jamapediatrics.2019.0855

30. Dignam T, et al. Control of lead sources in the united states, 1970-2017: public health progress and current challenges to eliminating lead exposure. J Public Health Manag Pract. 2019;25(Suppl 1):S13-22 Lead Poisoning Prevention (Suppl 1 LEAD POISONING PREVENTION).

31. O'Connor D, Hou D, Ye J, Zhang Y, Ok YS, Song Y, et al. Lead-based paint remains a major public health concern: a critical review of global production, trade, use, exposure, health risk, and implications. Environ Int. 2018;121(Pt 1):85-101. https://doi.org/10.1016/j.envint.2018.08.052.

32. Zamani $\mathrm{N}$, et al. Factors associated with high blood Lead levels in a sample of 100 children in Tehran. Clinical medicine insights. Pediatrics. 2019;13: 1179556518825451.

33. Organization, W.H. BMl-for-age. Growth reference 2007 [cited 2020 september 24]; Available from: https://www.who.int/growthref/who2007_ bmi_for_age/en/.

34. ASTM. Standard practice for field collection of dried paint samples for subsequent lead determination. 2016:E1729-E1716. West Conshohocken; ASTM. Available from: http://www.astm.org/cgi-bin/resolver.cgi?.

35. ASTM. Standard practice for collection of settled dust samples using wipe sampling methods for subsequent lead determination. West Conshohocken: ASTM International; 2020. p. E1728-E1728M-20.

36. National Center for Environmental Health, D.o.E.H.S.a.P. Sources of lead exposure. Lead Poison Prevent. 2019, 2019; [cited 2020 September 22]; Available from: https://www.cdc.gov/nceh/lead/prevention/sources.htm.

37. Alvand MH, Gholami Z, Ferrara M, Fabrizio E. Assessment of cost optimal solutions for high performance multi-family buildings in Iran. Energy Proc. 2017;111:318-27. https://doi.org/10.1016/j.egypro.2017.03.102.

38. Karbassi A, Moatar F, Monavari M, Mosayebi SS. The effect of air pollution on the concentration of heavy metals in the soil of Mellat Park. J Environ Sci Technol. 2009;11(4):51-64.

39. Frazer L. Soil in the city: a prime source of lead. Environ Health Perspect. 2008;116(12):A522. https://doi.org/10.1289/ehp.116-a522a.

40. Taghavi SN, et al. Assessment of heavy metals in street dusts of Tehran using enrichment factor and geo-accumulation index. Health Scope. 2019; 8(1):e57879.

41. Karbasi A, Nabii Bidhendi G, Moattar F, Barzegari Z. Evaluation of source and biological accessibility of heavy metals in the soil of Tehran northwestern elevations. J Environ Sci Technol. 2009;11(3):29-42.

42. McClain-Vanderpool, L. EPA and HUD announce new lead dust standards to protect children's health. 2019 [cited 2020 september 23]; Available from: https://www.epa.gov/newsreleases/epa-and-hud-announce-new-lead-duststandards-protect-childrens-health.

43. Hauptman M, Woolf AD. Childhood ingestions of environmental toxins: what are the risks? Pediatr Ann. 2017:46(12):e466-71. https://doi.org/10.392 8/19382359-20171116-01.

44. Othman ZAA. Lead contamination in selected foods from Riyadh city market and estimation of the daily intake. Molecules. 2010;15(10):7482-97.

45. Agency, U.S.E.P. Drinking Water Requirements for States and Public Water Systems 2020. [cited 2020 September 23]; Available from: https://www.epa. gov/dwreginfo/lead-and-copper-rule.

46. Savari J, Jaafarzadeh $\mathrm{N}$, Hassani AH, Khoramabadi GS. Heavy metals leakage and corrosion potential in Ahvaz drinking water distribution network. J Water Wastewater. 2007;18(4):16-24.

47. SHA MM, POUR MH, Sahmskhorraabadi G. A study of Leakage of trace metals from corrosion of the municipal drinking water distribution system. J Water Wastewater. 2003;8(3):30-4.

48. TASHAUOEI, H.R., et al., A study on leakage of heavy metals from the PVC and polypropylene pipes used in the water distribution system in Isfahan. 2010.

49. Mener DJ, Garcia-Esquinas E, Navas-Acien A, Dietert RR, Shargorodsky J, Lin SY. Lead exposure and increased food allergic sensitization in U.S. children and adults. Int Forum Allergy Rhinol. 2015;5(3):214-20. https://doi.org/10.1 002/alr.21460.

50. Afeiche M, Peterson KE, Sánchez BN, Schnaas L, Cantonwine D, Ettinger AS, et al. Windows of lead exposure sensitivity, attained height, and body mass index at 48 months. J Pediatr. 2012;160(6):1044-9. https://doi.org/10.1016/j. jpeds.2011.12.022.

51. Kim Y. The effects of blood low level heavy metals on short height: a propensity score matching analysis: Yu-Mi Kim. Eur J Public Health. 2016; 26(suppl_1):ckw174.196.

\section{Publisher's Note}

Springer Nature remains neutral with regard to jurisdictional claims in published maps and institutional affiliations. 